\title{
Psikolojik Sözleşme İhlalinin İş Performansına Etkisi: Duygusal Bağlılığın Aracılık Rolü
}

\section{The Effect of Psychological Contract Breach on Job Performance: The Mediating Role of Affective Commitment}

\author{
Ali Acaray ${ }^{a^{*}}$ \\ ${ }^{a}$ Dr. Öğr. Üyesi, Recep Tayyip Erdoğan Üniversitesi, Fındıklı Uygulamalı Bilimler Yüksekokulu, Bankacılık ve Finans Bölümü, 53700, Rize/Türkiye. \\ ORCID: 0000-0002-1002-9937
}

\section{MAKALE BİLGISI}

\section{Makale Geçmişi:}

Başvuru tarihi: 31 Mayıs 2019

Düzeltme tarihi: 20 Ekim 2019

Kabul tarihi:01 Kasım 2019

\section{Anahtar Kelimeler:}

Psikolojik Sözleşme İhlali

Duygusal Bağlilık

Görev Performansı

İşgören Sesliliği

\section{ARTICLE INFO}

\section{Article history:}

Received 31 May 2019

Received in revised form 20 October 2019

Accepted 01 November 2019

\section{Keywords:}

Psychological Contract Breach

Affective Commitment

Task Performance

Employee Voice
ÖZ

Bu çalışmanın amacı, psikolojik sözleşme ihlalinin iş performansına etkisini ve bu etkide duygusal bağlılığın aracılık rolünü incelemektir. Çalışma verilerinin toplanmasında anket tekniği kullanılmış olup kolayda örnekleme yöntemiyle bankalarda tam zamanlı biçimde çalışan 227 örneklem sayısına ulaşılmıştır. İş performansı; görev performansı ve işgören sesliliği olarak incelenmiştir. Çalışma sonucunda ulaşılan bulgulara göre; psikolojik sözleşme ihlali görev performansı ve işgören sesliliğini olumsuz olarak etkilemiş̧ir. Duygusal bağlılık değişkeninin de psikolojik sözleşme ihlalinin görev performansına etkisinde tam, işgören sesliliğine etkisinde ise kısmi aracılık rolü ortaya çıkmıştır. Ayrıca psikolojik sözleşme ihlali, çalışanların işgören sesliliklerini görev performansına göre daha fazla olumsuz olarak etkilemiştir.

\section{Giriş}

Çalışma yaşamında örgüt-çalışan arasındaki karşılıklı beklentilerin yerine getirilmemesi sorunu, çalışanların etkinlik ve verimliliği üzerine etkili olan temel konulardandır. $\mathrm{Bu}$ kapsamda da çalıșanların tutum ve davranışlarını şekillendiren öncüllerden biri psikolojik sözleşmelerdir. İşe alım sürecinde çalışanlardan beklenen ve bunun karşılığında onların ne elde edeceklerini açıklayan biçimsel sözleşmelerin çalışan ile örgüt arasındaki yükümlülükleri tam olarak ortaya koymakta yetersiz kalması, tarafların zihinlerinde oluşan fakat yazılı biçimde olmayan karşılıklı yükümlülüklerin yer aldığı psikolojik sözleşmeleri ortaya çıkarmıştır (Mimaroğlu, 2008). Çünkü tarafların birbirlerinden beklentileri sadece iş sözleşmelerindeki belirlenen koşullarla sınırlı değildir. Çalışanın örgütünden eğitim, iş güvencesi, kariyer gelişimi gibi konularda, örgütün de kendisinden gerektiğinde fazla mesaiye kalması, iş tanımındaki görevler haricindeki işleri yapması gibi konularda beklentileri söz konusudur (Restubog vd., 2006; Knights ve Kennedy, 2005; Robinson ve Rousseau, 1994). Çalışanların bu beklentilerin yerine

\footnotetext{
* Sorumlu yazar/Corresponding author.

e-posta: aliacaray@hotmail.com
} 
getirilmesi yükümlülüğüne ilişkin algıları psikolojik sözleşmeyi ortaya çıkarmaktadır (Çetinkaya, 2018). Psikolojik sözleşmeler; karş1lıklı beklentilerin yer aldığı, yazılı halde olmayan sözleşmeler olup (Rousseau, 1995; Levinson vd., 1962), tarafların birbirlerine ifade etmedikleri beklentileri içermektedir (Zhao vd., 2007). Ancak artan rekabet, hızla gelişen teknolojik gelişmeler ve getirdikleri, müşterilere kaliteli ürün ve hizmetler sağlanması gibi zorlu mücadeleler örgütleri küçülmeye, diğer şirketlerle birleşmelere, dış kaynak kullanmaya, operasyonlarını başka yerlerde sürdürmeye, yeniden yapılandırmalara yönlendirerek hali hazırdaki iş sözleşmelerinin gözden geçirilmesine yol açarak psikolojik sözleşme ihlalleriyle sonuçlanabilmektedir (Knights ve Kennedy, 2005). İhlal halleri de, bilhassa örgütlerin yeniden yapılanma dönemlerinde (Turnley ve Feldman, 1998) başka bir ifadeyle örgütsel değişmelerin olduğu koşullarda daha çok yaşanmaktadır (Robinson ve Morrison, 2000). Bir tarafın yükümlülüklerini veya vaatlerini yerine getirmemesi zihinlerdeki sözleşmeyi bozmakta ve karşılıklı yükümlülüklere dair sahip olunan inançlarda bir değişmeye yol açmaktadır (Doğan ve Demiral, 2009). Dolayısıyla çalışan, sözlerin yerine getirilmediğini hissettiğinde psikolojik sözleşme ihlal algısı meydana gelmektedir (Robinson ve Morrison, 2000). Psikolojik sözleşme ihlal algılaması, çalışanların verilen sözlerle yerine getirilen sözleri değerlendirmeleri neticesinde ulaştıkları bilişsel bir sonuçtur (Morrison ve Robinson, 1997).

Çalışanların yapılan anlaşmanın yükümlülüklerini örgütün yerine getirmediklerine dair inanca sahip olmalarının onların iş tutum ve davranışları üzerinde önemli bir etkiye sahiptir (Bal vd., 2011; Zhao vd., 2007; Robinson ve Morrison, 1995). Çalışanlar psikolojik sözleşme ihlalini algıladıklarında, sahip oldukları tutum ve davranışları olumsuz etkilenerek örgütün aleyhine çeşitli sonuçlar ortaya koyabilmektedir. İş performansının azalması bu sonuçlardan biridir (Harrison vd., 2006). İş performans1, örgütsel hedeflere ulaşılabilmesinde amaca yönelik davranışlardır (McShane ve Glinow, 2014). Dolayısıyla çalışanın performans1, örgütler için önemli bir iş performans kriteridir (Borman ve Motowidlo, 1997). Toplam iş performansı, çalışanların rol içi gösterdikleri görev performansları olarak görülse de, iş tanımlarında yer almayan, aynı zamanda olumlu bir davranış olarak da kabul edilen rol ötesi davranışlarını da (örneğin, işgören sesliliği, örgütsel vatandaşlık davranışı, bilgi paylaşma) kapsamaktadır.

Yapılan çalışmalarda psikolojik sözleşme ihlali ile çalışanların iş tatminleri (Aslan ve Uyar, 2018; Naeem vd., 2014; Knights ve Kennedy, 2005; Robinson ve Rousseau, 1994), örgütsel bağlılıkları (Johnson ve O'Leary-Kelly, 2003), performanslar1 (Restubog vd., 2007; Restubog vd., 2006; Robinson, 1996), örgütsel vatandaşlık davranışları (Restubog vd., 2007; Restubog vd., 2006; Robinson, 1996; Robinson ve Morrison, 1995), sorumluluk alma ve bilgi paylaşma düzeyleri (Bal vd., 2011) arasında negatif ilişkilerin olduğu ortaya konulmuştur. Beardwell (2007) de, psikolojik sözleşme ihlalinin çalışan bağlılı̆̆ 1 ve performansını azaltan, işe devamsızlık ve işten ayrılma niyetini artıran bir motivasyon engeli olarak hareket ettiğini ifade etmiştir.

Sosyal değişim teorisi (Blau, 1964), psikolojik sözleşme ihlalinin hangi yolla olumsuz sonuçlara neden olduğunu açıklamada teorik bir çerçeve sunmaktadır (Robinson ve Morrison, 1995; Rousseau, 1995). Sosyal değişim teorisi (Blau, 1964), bir taraf diğerine bir şey sağladığında (örneğin, görevlerini yerine getirdiğinde ya da iyilik yaptığında), diğer tarafin da buna karşıllk vermesini (örneğin, ekonomik koşulların iyileştirilmesini ya da iyilik yapmasını) beklediğini savunmaktadır. Dolayısıyla, örgütler vaat edilen yükümlülükleri ya da çalışanların girdilerine karşılık gerekli çıktıları sağlayamadıklarında ortaya çıkan psikolojik sözleşme ihlali ile haklarının yenildiğini düşünerek negatif duygulara sahip olabilecek ve böylece örgütlerine vaat ettikleri karşılıkları geri çekebileceklerdir. Bu kapsamda çalışanlar iş performanslarını (görev performansı ve işgören sesliliği) düşürebileceklerdir. $\mathrm{Bu}$ çalışmanın amacı, psikolojik sözleşme ihlalinin iş performansına etkisi ve bu etkide duygusal bağlılığın aracılık rolünü incelemektir. Psikolojik sözleşme ihlalinin çalışan performansını olumsuz olarak etkilediği yapılan çalışmalarda ortaya konulmakla beraber, bu iki değişken arasındaki işleyişin hangi faktörler vasıtasıyla ortaya çıkabileceğinin incelenmesi önemlidir. Bu rolü üstlenebilecek yapılardan birisi de duygusal bağlılıktır. Psikolojik sözleşme ihlali çalışanların duygusal bağlılıklarını azaltarak onların iş performanslarını düşürebilmektedir. Dolayısıyla psikolojik sözleşme ihlalinin çalışan performansına etkisinin duygusal bağlılık üzerinden nasıl ortaya çıkabileceğinin ele alınması önemli olmaktadır.

Çalışmanın uygulama kısmı, bankacılık sektörü çalışanlarından toplanan anket verilerinin analizini içermektedir. Örneklemin bu sektörden seçilmesinin nedeni ise, artan rekabet baskısı, teknolojik gelişim ve getirdikleri gibi koşulların iş performansını daha da önemli hale getirmesidir. Dolayısıyla çalışanların biçimsel iş tanımlarındaki görevleri yerine getirerek ve bununla da yetinmeyerek gönüllü davranışlar sergilemesi kurumların başarısında gereklidir. Bankalar açısından önem arz eden bir konunun öncüllerinin ortaya konulabilmesi yöneticilerin insan kaynakları uygulamalarında kullanabileceği takım çantasını zenginleştirebilir. Yöneticilerin psikolojik sözleşme ihlallerinin çalışan tutum ve davranışlarını nasıl etkilediğini anlamalarına yardımcı olabilir. Bankalar açısından önem arz eden bir konunun öncüllerinin ortaya konulabilmesi yöneticilerin insan kaynakları uygulamalarında kullanabileceği takım çantasını zenginleştirebilir. Yöneticilerin psikolojik sözleşme ihlallerinin çalışan tutum ve davranışlarını nasıl etkilediğini anlamalarına yardımcı olabilir.

\section{Kavramsal Çerçeve ve Hipotez Geliştirme}

\subsection{Psikolojik Sözleşme İhlali}

Psikolojik sözleşme kavramı ilk defa Argyris (1960) tarafından kullanılarak "çalışan ve işverenin karşılıklı yükümlülüklere, beklentilere ve arzulara dair resmi iş sözleşmelerinin üzerinde oluşturulan anlaşma" biçiminde tanımlanmıştır (Smithson ve Lewis, 2004: 70). Rousseau (1989) da, psikolojik sözleşmeyi bireyin karşılıklı değişim anlaşmasında diğer taraftan beklentisi olarak tanımlayarak, psikolojik sözleşmenin taraflar arasındaki karşılıklı değişim ilişkisi üzerine kurulduğunu ifade etmiştir. Psikolojik sözleşme kavramı, örgüt ve çalışanların taraflar olarak birbirlerine karşı yükümlülüklerin yer aldığı biçimsel sözleşmelerden daha fazla içeriğe sahiptir (Robinson ve 
Morrison, 2000). Psikolojik sözleşmenin ihlali ise, çalışanların örgütlerinin beklentilerini yerine getirmediğini algıladıklarında ortaya çıkar (Robinson ve Morrison, 1995; Robinson ve Rousseau, 1994). Psikolojik sözleşme ihlali, sözleşmede yer alan bir ya da daha fazla yükümlülüğün örgütlerce yerine getirilmemesi şeklinde ifade edilmektedir (Robinson ve Rousseau, 1994). Vaat edilen bir şeyin ifade edilmesi çalışanda bir beklentiye dönüşür ve vaadin yerine getirilmemesi durumunda ise psikolojik sözleşmenin ihlal edildiği algısı oluşur (Robinson ve Morrison, 2000). İhlal algısı halinde çalışanlarda örgütlerine karşı öfkeli olma, güven ve sadakatin azalması, üzüntü gibi duygular oluşabilir (Robinson ve Rousseau, 1994). Bu bağlamda psikolojik sözleşme ihlali, çalışanların duygusal reaksiyonlarını harekete geçiren önemli bir örgütsel hadisedir (Zhao vd., 2007). Çalışanların da psikolojik sözleşmelerinin örgütler tarafından sıklıkla ihlal edildiğine inandıkları ifade edilmektedir (Örücü ve Korkmaz, 2018).

\section{2. İş Performans1}

Yönetim yazınında en çok çalışılan konulardan biri olarak iş performansı, çalışanların örgütsel hedeflerin gerçekleştirilmesinde ortaya koydukları davranışlar neticesinde ulaşılan sonuçlardır (Bağc1, 2014). Williams ve Anderson (1991) da iş performansını, örgütün amaç ve hedeflerine uygun biçimde sergilenen davranışlar bütünü olarak tanımlamıştır. İş performansı rol içi performans ve ekstra rol davranışı şeklinde çoklu bir yapı olarak ortaya çıkmaktadır (Podsakoff vd., 2000; Borman ve Motovidlo, 1997). Rol içi performans kapsamında görev performansı, çalışanların biçimsel iş tanımlarındaki temel faaliyetlerin yerine getirilmesinde gerekli görev ve sorumluluklar kümesine ilişkin performans türüdür (Befort ve Hattrup, 2003; Williams ve Anderson, 1991). Rol ötesi performans kapsamında işgören sesliliği ise, çalışanların işe dair şikâyetlerini, endişelerini üst yönetime bildirmesidir (Arslan ve Yener, 2016). Böyle bir davranış temel iş gereksinimlerinin dışında gönüllü olarak ortaya konulan davranışlardır (Podsakoff vd., 2000). İşgören sesliliği, çalışanın resmi iş tanımlarının dışında ekstra sorumluluk yüklenmelerini gerektirir (Van Dyne vd., 1995).

Psikolojik sözleşme ihlali, çalışanlarda örgütün vaatlerini yerine getirmemesi halinde ortaya çıkan bir algılama olduğu için, çalışanlar bu duruma karşılık birçok şekilde cevap verebilecektir. Sosyal değişim teorisine (Blau, 1964) göre de, işverenler vaatlerini ve yükümlülüklerini yerine getirmediğinde, çalışanlar örgütteki çabalarını azaltarak karşılık verirler. Algılanan psikolojik sözleşme ihlali, çalışanın örgütüne olan güveninde aşınma başlatır ve bu durum da çalışanın örgüte sağladığı faydaların azalmasını beraberinde getirebilmektedir (Robinson, 1996). Bu nedenle, psikolojik sözleşme ihlalinin görev performansını ve işgören sesliliğini olumsuz yönde etkilemesi beklenmektedir. Ayrıca psikolojik sözleşme ihlali nedeniyle çalışanların gösterecekleri reaksiyonlardan ilki örgütün lehine gönüllü olarak ve yapılmaması durumda da bir karşılığının olmayacağı davranışları sergilemeyebileceklerdir. Dolayısıyla çalışanlar öncelikle seslilik davranışlarında değişikliğe gidebileceklerdir. Yapılan çalışmalarda da psikolojik sözleşme ihlali ile rol içi ve rol dışı davranışlar arasında negatif ilişkilerin olduğu görülmektedir. Psikolojik sözleşme ihlali iş performansı ile olumsuz bir ilişkiye sahiptir (Zhao vd., 2007). Johnson ve O'Leary-Kelly’nin (2003) yaptığı çalışmada psikolojik sözleşme ihlalinin görev performansı üzerine negatif bir etkisi olduğu ortaya konulmuştur. Restubog vd. (2006) tarafindan yapılan araştırma sonucunda da rol içi performans üzerinde psikolojik sözleşme ihlalinin negatif bir etkisi olduğu ortaya çıkmıştır. Başka bir çalışmada da psikolojik sözleşme ihlalinin görev performansını negatif olarak etkilediği tespit edilmiştir (Hussain vd., 2016).

Bal vd. (2010) çalışmalarında psikolojik sözleşme ihlalinin örgütsel vatandaşlık davranışına etkisinin negatif olduğunu ortaya koymuşlardır. Bal vd. (2011) tarafindan yapılan çalışmada da psikolojik sözleşme ihlali ile proaktif davranışlardan bilgi paylaşma ve sorumluluk alma arasında negatif bir ilişki olduğu ortaya çıkarılmıştır. Psikolojik sözleşmenin ihlal edilmesi hem örgüte hem de bireye yönelik vatandaşlık davranışları ve ayrıca biçimsel performansa negatif bir etkisi söz konusudur (Restubog vd., 2007). Dolayısıyla yapılan çalışmalara ve ilgili teoriye dayanarak aşağıdaki hipotezler geliştirilmiştir:

H1a: Psikolojik sözleşme ihlali görev performansı üzerinde negatif ve anlamlı bir etkiye sahiptir.

H1b: Psikolojik sözleşme ihlali işgören sesliliği üzerinde negatif ve anlamlı bir etkiye sahiptir.

\subsection{Duygusal Bağl11ık}

Örgütsel bağlılığın unsurlarından olan duygusal bağlılık, çalışanların duygusal bir ilgi oluşturarak örgütleriyle özdeşleşmeleri halidir (Meyer ve Allen, 1991). Böyle bir duygusal yapıda çalışanlar örgütlerine sadakat, mutluluk ve huzurla bağlı hissetmektedirler (Tükeltürk, Perçin ve Güzel, 2012). Duygusal bağlılığın temeli olan çalışanın kendisi istediği için örgüt üyeliğine devam etme düşüncesi, ihtiyaç duyulduğu için örgütte kalmaya devam etmesi (normatif bağlılık) ile mecbur hissedildiği için örgütten ayrılmak istememe (devamlılık bağlılığı) düşüncelerinden farklıdır (Allen ve Meyer, 1990). Örgütler açısından önemli bir çalışan tutumu olan duygusal bağın güçlü biçimde ortaya çıkabilmesi için çalışanların örgütün amaç ve hedeflerini sahiplenmesi, içten gelen bir motivasyonla çalışmayı ve örgütte kalmaya devam etmeyi istemesi gerekir (Yorulmaz, 2018). Güçlü bir duygusal bağlılık iş performansı ve daha özelde de örgütsel vatandaşlık davranışı gibi önemli davranışlar üzerinde güçlendirici bir etkiye sahiptir (Cropanzano vd., 2003).

Psikolojik sözleşmede yer alan sözlerin tutulmaması, beklentilerin karşılanmaması neticesinde ortaya çıkabilecek ihlal algısı çalışanların örgütlerine olan güven duygularına zarar verebilecektir (Bal vd., 2008). Buna bağlı olarak çalışanların duygusal bağlılıklarında bir azalma söz konusu olabilecektir. Ayrıca ihlal algısı çalışanları iş tatminsizliğine de götüren bir faktördür (Robinson ve Morrison, 1995; Robinson ve Rousseau, 1994). İş tatminsizliği de duygusal bağlılığı azaltan tutumlardan biridir (Varol, 2017). Yapılan çalışmalarda örgütsel bağlılığın azalmasına yol açan faktörlerden birinin de psikolojik sözleşme ihlali olduğu ifade edilmektedir (Robinson, 1996; Robinson ve Morrison, 1995; Robinson ve Rousseau, 1994). Bal vd. (2008) de yaptıkları meta analiz çalışmalarında, duygusal olaylar teorisi (Weiss ve Cropanzano, 1996) ve sosyal değişim teorisi temelinde psikolojik sözleşme ihlalinin güven, iş 
tatmini ve duygusal bağlılık gibi iş tutumlarıyla negatif ilişki içerisinde oldukları sonucuna varmışlardır. Zhao vd. (2007) yaptıkları meta analiz çalışmalarında psikolojik sözleşmenin ihlal edilmesinin çalışanların bağlılık, iş tatmini ve örgütsel vatandaşlık davranışları gibi çeşitli tutum ve davranışlarını olumsuz olarak etkilediğini ortaya koymuşlardır. Restubog vd.'nin (2006) yaptıkları araştırmada, psikolojik sözleşme yükümlülüklerinin yerine getirilmesinde örgütün başarısızlığı halinde çalışanlarda moral bozukluğu ve duygusal bağlılıklarında zayıflama ve böylelikle de sivil erdem davranışlarında azalma meydana geldiği tespit edilmiştir. Yapılan çalışmalardan görüldüğü üzere psikolojik sözleşme ihlali çalışanların duygusal bağlılıkları ve iş performansları üzerine olumsuz etkilere sahiptir. Buradan ihlal algısının çalışanların duygusal bağlılığında bir aşınmaya yol açarak devamında da iş performanslarını (görev performansı ve işgören sesliliği) azaltacağı beklenmektedir. İlgili yazında psikolojik sözleşme ihlali ile sivil erdem (Restubog vd., 2006), duygusal tükenme ile örgütsel vatandaşlık davranışı ve iş performansı (Cropanzano vd., 2003) arasında duygusal bağlılığın aracılık rolü üstlenebildiğine dair çalışmalar mevcuttur. Dolayısıyla yapılan açıklamalar ve çalışmalara dayanarak aşağıdaki hipotezler geliştirilmiştir:

H2a: Duygusal bağlılık, psikolojik sözleşme ihlalinin görev performansına etkisinde aracılık rolüne sahiptir.

H2b: Duygusal bağlılık, psikolojik sözleşme ihlalinin işgören sesliliğine etkisinde aracılık rolüne sahiptir.

Psikolojik sözleşme ihlalinin iş performansını etkisi ve bu etkilemede duygusal bağlılığın aracılık rolüne sahip olup olmadığını açığa çıkarmak için geliştirilen hipotezler Şekil 1 'de görülmektedir.

Şekil 1. Araştırmanın Modeli

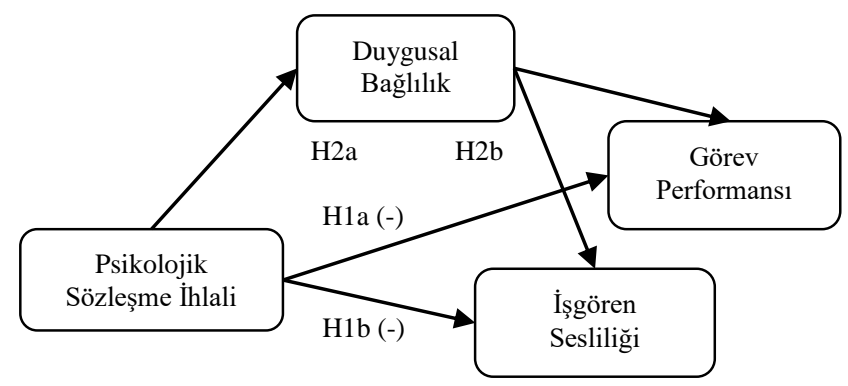

\section{Araștırma}

\section{1. Örnekleme Süreci ve Demografik Özelliklere Dair Tanımlayıcı Bilgiler}

Araştırmanın evrenini Doğu Karadeniz Bölgesi’ndeki (Trabzon, Rize ve Artvin illeri) bankacılık sektöründe faaliyetlerini sürdüren mevduat bankalarındaki tam zamanlı çalışanlar oluşturmuştur. Verilerin toplanmasında kolayda örnekleme yöntemi kullanılmıştır. Veriler, 2018 yılının Ekim ve Kasım aylarında ilgili illerdeki banka çalışanlarından anket tekniği ile toplanmıştır. Anketlerin dağıtıldığı illerin bankalarında 2018 yılı sonu itibari toplam çalışan sayısı 2.335'tir (Trabzon=1519, Rize=490 ve Arvin=326) (Türkiye Bankalar Birliği Veri Sistemi, 2018). Trabzon ilindeki bankalara 450 (anketleri dolduranların sayısı; 105), Rize ilindeki bankalara 225 (anketleri dolduranların sayısı; 110) ve Artvin ilindeki bankalara ise 120 anket (anketleri dolduranların sayısı; 54) elden dağıtılmıştır. Toplam geri toplanan anket sayısı 269'dur. İçlerinden 42 tanesi eksik ve gelişigüzel doldurulmuş olmasi nedeniyle analize katılmamıştır. Örneklem sayısı 227 olarak ortaya çıkmıştır. Ankete cevap verenlerin; \% 55,5'i erkek, \% 77,1'i üniversite mezunu, ortalama yaşı 33,08 (ss:5,70), ortalama çalışma geçmişi 8,09 yıl (ss:5,36) ve \% 69,2'si evli ve daha çok müşteri temsilcisi $(\% 47,1)$ olarak ortaya çıkmıştır.

\subsection{Araştırma Ölçeklerinin Oluşturulması}

Katılımcılara demografik bilgilerinin öğrenilmesi, psikolojik sözleşme ihlali, duygusal bağlılık, görev performansı ve seslilik algılamalarının ölçülmesinde çeşitli sorular yöneltilmiştir. Demografik bilgilere ilişkin altı adet soru sorulmuştur. Ölçek maddelerin ölçümlenmesinde $1=$ Kesinlikle katılmıyorum ve $5=$ Kesinlikle katıliyorum şeklindeki 5'li likert tipi ölçekler kullanılmıştır.

Çalışanların psikolojik sözleşme ihlal algıları Robinson ve Morrison'un (2000) geliştirdiği ölçeğin 5 maddesi kullanılarak ölçülmüştür. Ölçek maddelerinden birisi de "İşverenimin, işe alındığımdan beri bana vermiş olduğu sözleri yerine getirdiğini düşünmekteyim" şeklindedir. Ölçekteki üç madde ters biçimde kodlanmıştır. Robinson ve Morrison'un (2000) yaptığı çalışmada psikolojik sözleşme ihlalinin güvenilirliği 0,92 olarak hesaplanmıştır.

Çalışanların duygusal bağlılık algıları Meyer ve Allen'in (1991) ortaya koyduğu üç boyuttan oluşan bağlılık sınıflamasını dikkate alarak Wasti'nin (2000) geliştirdiği 8 maddeden oluşan ölçek kullanılarak ölçülmüştür. Ölçek maddelerinden birisi de "Bu kurumun sorunlarını kendi sorunlarım gibi hissediyorum" şeklindedir. Wasti'nin (2000) yaptığı çalışmada duygusal bağlılığın güvenilirliği 0,79 olarak hesaplanmıştır.

Çalışanların görev performans algıları Williams ve Anderson'ın (1991) geliştirdiği 7 maddeden oluşan tek boyutlu ölçek kullanılarak ölçülmüştür. Ölçek maddelerinden birisi de "Bana verilen görevleri yeterli düzeyde yerine getiririm" şeklindedir. Williams ve Anderson'ın (1991) çalışmasında görev performansının güvenilirliği 0,86 olarak hesaplanmıştır.

Çalışanların seslilik davranışları ise Van Dyne ve LePine'nin (1998) geliştirdiği 6 maddeden oluşan tek boyutlu ölçek kullanılarak ölçülmüştür. Ölçeğin Türkçe'ye uyarlanması Arslan ve Yener (2016) tarafından yapılmıştır. Ölçek maddelerinden birisi de " $\mathrm{Bu}$ kurumda iş sürecini kolaylaştıracak yeni fikirler ve değişiklikler hakkında amirlerimle rahatça konuşabilirim" şeklindedir. Arslan ve Yener'in (2016) çalışmasında ölçeğin güvenilirliği 0,76 olarak hesaplanmıştır.

\subsection{Verilerin Analizi}

Araştırmada kullanılan ölçeklerin geçerlilik ve güvenilirlik tespitlerinde SmartPLS 3.0 programından yararlanılmıştır. Ortaya konulan modelin geçerlilik ve güvenilirliklerinin ölçümü ve parametrelerinin hesaplanmasında yapısal eşitlik modellemesi kapsamında kısmi en küçük kareler (PLSPartial Least Squares) kullanılmıştır. PLS, yapısal eşitlik modelinin (YEM) test edilmesinde kovaryans tabanlı klasik yaklaşımlardan (AMOS ve LISREL gibi) farklı olarak 
bileșen tabanlı yeni bir yaklaşımdır. Bununla birlikte PLS, küçük örneklemlerle analizlerin ve karmaşık modellerin tahminin yapılabilmesinde elverişli bir yöntem şeklidir. Bileşen tabanlı bir YEM yaklaşımı olan PLS'nin bir diğer farkı da, normal dağılım göstermeyen verilerin analizinde kullanılabilmesidir (Chin, 2001). Bu çalışma kapsamında örneklem verilerinin normal dağılmadığı görülmüş (Tablo 1) olup, analizlerin yapılmasında bir yapısal eşitlik modellemesi olan SmartPLS 3.0 kullanılmıştır.

Yapısal modelin test edilmesi yanı sıra örneklemin demografik özelliklerinin incelenmesi ve normallik testlerinin yapılmasında SPSS v23 istatistik programından yararlanılmıştır.

\section{Bulgular}

\subsection{Normallik Testine Dair Bulgular}

Araştırma verilerinin normal dağılım gösterip göstermediğine ilişkin temelde basıklık (kurtosis) ve çarpıklık (skewness) değerlerine ve bununla ilgili yapılan test sonuçlarına bakılmaktadır. Hesaplanan Kurtosis ve Skewness değerlerinin $-1,5$ ile $+1,5$ arasında olması durumunda normal dağılım gösterdiği kabul edilmektedir (Tabachnick ve Fidell, 2013). Ancak ulaşılan değerler (Tablo 1) bakımından görev performansı ve işgören sesliliği faktörlerine dair verilerin ilgili referans aralığında olmaması nedeniyle normal dağılıma sahip olmadığ 1 söylenebilir. Ayrica analizlerde Kolmogorov-Smirnov ve Shapiro-Wilk testlerinde faktörlerin anlamlılık değerlerinin 0,05 'ten küçük olmasından dolayısıyla da verilerin normal dağılım göstermediği ifade edilebilir.

Tablo 1. Faktörlerin Normal Dağılım İstatistik Sonuçları

\begin{tabular}{lcccccc}
\hline \multicolumn{1}{c}{ Faktör } & $\begin{array}{c}\text { Kolmo } \\
\text { gorov } \\
\text { Smirnov }\end{array}$ & $\mathrm{p}$ & $\begin{array}{c}\text { Sha } \\
\text { piro- } \\
\text { Wilk }\end{array}$ & $\mathrm{p}$ & $\begin{array}{c}\text { Kurto } \\
\text { sis }\end{array}$ & $\begin{array}{c}\text { Skew } \\
\text { ness }\end{array}$ \\
\hline $\begin{array}{l}\text { Psikolojik } \\
\text { Sözleşme İhlali }\end{array}$ &, 176 &, 000 &, 935 &, 000 &, 078 &, 630 \\
\hline $\begin{array}{l}\text { Duygusal } \\
\text { Bağlilık }\end{array}$ &, 110 &, 000 &, 945 &, 000 & 1,141 &,- 847 \\
\hline $\begin{array}{l}\text { Görev } \\
\text { Performansı }\end{array}$ &, 223 &, 000 &, 808 &, 000 & 4,363 & $-1,637$ \\
\hline İşgören Sesliliği &, 167 &, 000 &, 914 &, 000 & 1,618 &,- 1037 \\
\hline
\end{tabular}

\section{2. Ölçüm Geçerlilik ve Güvenilirliğine Dair Bulgular}

Ölçeklerin yapısal geçerliliği doğrulayıcı faktör analizi ile (CFA), güvenilirlikleri ise Cronbach's Alfa ( $\alpha \geq .70)$, bileşik güvenilirlik $(\mathrm{CR} \geq .70)$ ve hesaplanan ortalama varyans (AVE $\geq .50)$ ile analiz edilmiştir (Hair vd., 2016).

Örneklem verilerinin faktör analizine yeterli olup olmadığına yönelik gerçekleştirilen ilk ölçümlerde KMO değerleri; psikolojik sözleşme ihlali 0,721, duygusal bağlılık 0,909, görev performans1 0,892 ve işgören sesliliği 0,889 olarak ortaya çıkmıştır. KMO değerlerinin kabul edilip edilmemesinde kritik değer 0,50 olup (Field, 2000); ölçeklerin hesaplanan KMO değerleri 0,50’yi geçtiği için faktör analizi yapılmıştır. Açıklanan toplam varyanslar değerlendirildiğinde ise, psikolojik sözleşme ihlalinin beş maddesi \% 77,09, duygusal bağlılı̆̆ın sekiz maddesi \% 67,79, görev performansının yedi maddesi \% 72,92 ve işgören sesliliğinin altı maddesi de \% 71,59 oranında açıklamaktadır.
Ölçeklerin CFA'sına ilișkin sonuçları Tablo 3'te görülmekte olup; ulaşılan yükler eşik değer olan 0,50'yi karşılaşmıştır. Bununla birlikte modelde incelenen değişkenlerin AVE, CR ve Alfa değerleri ise Tablo 3'te görülmektedir. Ayrışma geçerliliğinde ise, her bir değișkende AVE'nin hesaplanan karekökünün değişken çiftleri arasındaki korelasyondan yüksek çıkması gerekir (Fornell ve Larcker, 1981). Tablo 4'teki parantez arasındaki değerler ayrışma geçerliliği sonuçlarına dair değerler olup, herhangi bir sorun olmadığı görülmektedir. Ayrıca ayrışma geçerliliğinin sağlanıp sağlanmadığına ilişkin olarak HTMT değerlerinin 0,90'nın altında olması koşulunu sağlaması gerekmektedir (Doğan, 2019). Tablo 2'deki değerler bu koşulun karşılandığını göstermiş ve böylece ayrışma geçerliliği sağlanmıştır.

Tablo 2. HTMT Değerleri

\begin{tabular}{lcccc}
\hline \multicolumn{1}{c}{ Değişkenler } & $\begin{array}{c}\text { Psikolojik } \\
\text { Sözleşme } \\
\text { İhlali }\end{array}$ & $\begin{array}{c}\text { Duygusal } \\
\text { Bağl1lı }\end{array}$ & $\begin{array}{c}\text { Görev } \\
\text { Performansı }\end{array}$ & $\begin{array}{c}\text { İşgören } \\
\text { Sesliliği }\end{array}$ \\
\hline $\begin{array}{l}\text { Psikolojik } \\
\text { Sözleşme İhlali }\end{array}$ & - & & \\
\hline $\begin{array}{l}\text { Duygusal } \\
\text { Bağlılık }\end{array}$ & 0,654 & - & \\
\hline $\begin{array}{l}\text { Görev } \\
\text { Performansı }\end{array}$ & 0,408 & 0,700 & - & - \\
\hline İşören Sesliliği & 0,587 & 0,668 & 0,664 & - \\
\hline
\end{tabular}

Dolayısıyla yapılan testler neticesinde değişkenlerin tek boyutluluk ve gerekli geçerlilik ve güvenirlik koşullarını yerine getirdiği görülmektedir.

Tablo 3. Doğrulayıcı Faktör Analiz Sonuçları

\begin{tabular}{|c|c|c|c|c|c|}
\hline Ölçekler & Maddeler & Faktör Yükleri & AVE & $\mathrm{CR}$ & Alfa \\
\hline \multirow{5}{*}{ 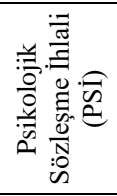 } & PSİ 1 & 0,873 & \multirow{5}{*}{0,565} & \multirow{5}{*}{0,862} & \multirow{5}{*}{0,801} \\
\hline & PSİ 2 & 0,825 & & & \\
\hline & PSİ 3 & 0,804 & & & \\
\hline & PSİ 4 & 0,489 & & & \\
\hline & PSİ 5 & 0,704 & & & \\
\hline \multirow{8}{*}{ 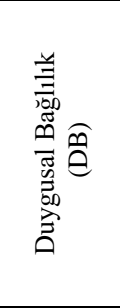 } & DB 1 & 0,549 & \multirow{8}{*}{0,676} & \multirow{8}{*}{0,943} & \multirow{8}{*}{0,929} \\
\hline & DB 2 & 0,833 & & & \\
\hline & DB 3 & 0,874 & & & \\
\hline & DB 4 & 0,868 & & & \\
\hline & DB 5 & 0,871 & & & \\
\hline & DB 6 & 0,824 & & & \\
\hline & DB 7 & 0,882 & & & \\
\hline & DB 8 & 0,825 & & & \\
\hline \multirow{7}{*}{ 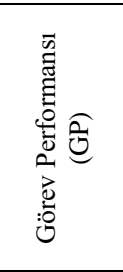 } & GP 1 & 0,778 & \multirow{7}{*}{0,729} & \multirow{7}{*}{0,949} & \multirow{7}{*}{0,938} \\
\hline & GP 2 & 0,853 & & & \\
\hline & GP 3 & 0,885 & & & \\
\hline & GP 4 & 0,836 & & & \\
\hline & GP 5 & 0,838 & & & \\
\hline & GP 6 & 0,891 & & & \\
\hline & GP 7 & 0,890 & & & \\
\hline \multirow{6}{*}{ 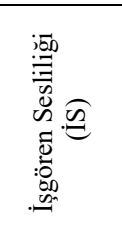 } & İS 1 & 0,843 & \multirow{6}{*}{0,715} & \multirow{6}{*}{0,938} & \multirow{6}{*}{0,920} \\
\hline & İS 2 & 0,867 & & & \\
\hline & İS 3 & 0,851 & & & \\
\hline & İS 4 & 0,829 & & & \\
\hline & İS 5 & 0,816 & & & \\
\hline & İS 6 & 0,867 & & & \\
\hline
\end{tabular}

Değişkenlerin birbirleri ile olan ilişkilerinin incelenmesinde korelasyon analizi uygulanmıştır. Tablo 4'teki korelasyon analiz sonuçlarına göre; psikolojik sözleşme ihlali ile duygusal bağlılık $(\mathrm{r}=-0,57, \mathrm{p}<0,01)$, psikolojik sözleşme ihlali ile görev performansı $(r=-0,35, p<0,01)$, psikolojik 
sözleşme ihlali ile işgören sesliliği $(r=-0,49, \mathrm{p}<, 01)$ arasında negatif ilişkiler söz konusudur.

Tablo 4. Korelasyon Değerleri

\begin{tabular}{clcccc}
\hline Sira & Değişkenler & $(1)$ & $(2)$ & $(3)$ & (4) \\
\hline \multirow{2}{*}{$(1)$} & Psikolojik & & & \\
& Sözleşme İhlali & $(0,75)$ & & & \\
\hline$(2)$ & Duygusal Bağlılık & $-0,57^{* *}$ & $(0,82)$ & & \\
\hline$(3)$ & Görev Performans1 & $-0,35^{* *}$ & $0,66^{* *}$ & $(0,85)$ & \\
\hline$(4)$ & İşören Sesliliği & $-0,49^{* *}$ & $0,62^{* *}$ & $0,62^{* *}$ & $(0,84)$ \\
\hline Ortalama & 2,42 & 3,69 & 4,07 & 3,86 \\
& Standart Sapma &, 80 &, 82 &, 76 &, 82 \\
\hline
\end{tabular}

$\mathrm{N}: 227, * \mathrm{p}<, 05, * * \mathrm{p}<, 01$. Parantez içerisindeki değerler ayrışma geçerlilik değerleridir.

\subsection{Hipotez Testleri}

Araştırma modelinin gücünün ve değişkenler arası ilişkilerin belirlenebilmesinde en küçük kareler (PLS) yol analizi; beklenen ilişkilerin istatistiki açıdan anlamlı olup olmadıklarının testi ise SmartPLS programında önyükleme yapılarak yeniden-örnekleme yöntemi kullanılarak yapılmıştır (Chin vd., 2003). Yeniden-örnekleme süreci orijinal verilerin yerine tesadüfi biçimde seçilen 5000 altörneklem oluşturmayı içermektedir (Hair vd., 2013). Tesadüfi biçimde seçilen her bir alt-örneklemin yol katsayıları $(\beta)$ ve t-istatistik değerleri hesaplanmıştır (Tablo 5).

Tablo 5. Hipotez Test Sonuçları

\begin{tabular}{lccccccc}
\hline & Yol & & B & t & p & Hipotez & Sonuç \\
\hline PSI & $\rightarrow$ & GP &,- 37 & 5,620 &, 000 & H1a & Desteklendi \\
\hline PSİ & $\rightarrow$ & İS &,- 51 & 8,617 &, 000 & H1b & Desteklendi \\
\hline$* \mathrm{p}<0,05 . * * \mathrm{p}<0,01$ & & & & &
\end{tabular}

PSİ: Psikolojik Sözleşme İhlali, GP: Görev Performansı, İS: İşgören Sesliliği

Psikolojik sözleşme ihlalinin görev performansı $(\beta=-0,37$, $\mathrm{p}<0,01)$ üzerine etkisi negatif olup istatistiksel açıdan anlamlıdır. Dolayısıyla H1a hipotezi desteklenmiştir.

Psikolojik sözleşme ihlalinin işgören sesliliği $(\beta=-0,51$, $\mathrm{p}<0,01)$ üzerine etkisi negatif olup istatistiksel açıdan anlamlıdır. Dolayısıyla H1b hipotezi de desteklenmiştir.

Geliştirilen yapısal modelin gücüne bakıldığında, psikolojik sözleşme ihlalinin duygusal bağlılık ile birlikte görev performansındaki değişimin \% 43'ünü $\left(\mathrm{R}^{2}=0,43\right)$, işgören sesliliğindeki değişimin \% 42'sini $\left(\mathrm{R}^{2}=0,42\right)$ ve psikolojik sözleşme ihlalinin duygusal bağlılıktaki değişimin ise \% 33'ünü $\left(\mathrm{R}^{2}=0,33\right)$ açıkladığı tespit edilmiştir.

Araştırmanın uyum indislerine bakıldığında, $\chi 2 / \mathrm{df} 0,939$ ile 3'ün altında bir değerle ve SRMR (Standardized Root Mean Square Residual) ise 0,078 ile 0,080'nin altında bir değerle gerekli eşikleri geçtiğ görülmüştür. Ayrıca NFI (Normative Fit Index) da 0,812 bir değerle 0,80-0,90 arasında olup iyi kabul edilebilecek bir düzeydedir. Dolayısıyla bu sonuçlar, yapısal modelin gerekli kriterleri karşılamasında sorun olmadığını göstermektedir.

Duygusal bağlılı̆̆ın aracılık testine ilişkin işlemler, SmartPLS programı yardımıyla toplam etki yöntemi takip edilerek gerçekleştirilmiştir. Aracılık testlerinde toplam etki yönteminin tahmin yapabilmede Sobel testi, güç analizi, Tip I ve II hata testleri (MacKinnon vd., 2004) gibi test yöntemlerine göre daha iyi sonuçlar verdiği ifade edilmektedir (MacKinnon vd., 2004). Aracı değişkeninin aracılık rolünün çözümlenebilmesinde dolaylı etkilerin anlamlılık testi, hem aracı değişkenlerin modele dahil edilmemesi ( $\mathrm{C}$ yolu ile gösterilen toplam etki) hem de dahil edilmesi ( $C^{\prime}$ yolu ile gösterilen direkt etki) durumlarında yapılmalıdır. Baron ve Kenny'nin (1986) aracılık rolü test işlemleri de bu mantığa dayalıdır: i) bağımsız değişkenin aracı değişken üzerine etkisi; ii) aracı değişkenin bağımlı değişken üzerine etkisi ve iii) bağımsız değişkenin de bağımlı değişken üzerine etkisi olmalıdır. Bağımsız ile aracı değişkenin birlikte modele dahil edilmesi halinde bağıml değişken üzerinde ortaya çıkan etki incelendiğinde ise, ya bağımsız değişkenin etkisinde bir azalma olması (kısmi aracı etkisi) ya da bağımsız değişkenin etkisini tamamen yitirmesi gerekir (tam aracı etkisi). Bununla birlikte etki oranlarının $\left(\mathrm{R}^{2}\right) \mathrm{da}$, ara etkilerle aracı(lar) aracılığıyla açıklanan toplam etkinin miktarının ortaya çıkarılması gerekir. Sonuç olarak, burada izah edilen toplam etki yöntemi; aracılık rolünün belirlenebilmesinde kullanılan nicel bir yöntem türü olarak, tam ve kısmi aracılığın hesaplanabilmesinde kullanılabilmektedir (Shrout ve Bolger, 2002).

Tablo 6'da, psikolojik sözleşme ihlali ile hem görev performansı hem de işgören sesliliği arasındaki dolaylı ilişkiler görülmektedir.

Tablo 6. Yapısal Modeldeki Dolaylı Etki

\begin{tabular}{llll}
\hline & \multicolumn{1}{c}{ İlişki } & & $\begin{array}{c}\text { Dolaylı Etki } \\
(\beta)\end{array}$ \\
\hline PSI -> & Duygusal Bağlılık -> & GP & $-0,375^{* *}$ \\
\hline PSI -> & Duygusal Bağlılık -> & İS & $-0,287^{* *}$ \\
\hline
\end{tabular}

Psikolojik sözleşme ihlalinin hem görev performansı hem de işgören sesliliği üzerine etkisinde duygusal bağlılığın aracılık rolüne ilişkin ulaşılan sonuçlar Tablo 7'de sunulmaktadır.

Tablo 7. Aracı Değişken Testi

\begin{tabular}{lllll}
\hline \multirow{2}{*}{$\begin{array}{l}\text { Duygusal Bağlılığın } \\
\text { Aracı Rolü }\end{array}$} & $\begin{array}{l}\text { Toplam } \\
\text { Etki C yolu }\end{array}$ & $\begin{array}{l}\text { Toplam } \\
\text { Etki C' yolu }\end{array}$ & $\begin{array}{l}\text { Etki } \\
\text { Oranı }\end{array}$ \\
\cline { 2 - 4 } & $(\beta)$ & $(\beta)$ & \\
\hline PSİ $->$ & GP & $-0,373^{* *}$ & 0,021 & 1,00 \\
\hline PSİ -> IS & $-0,514^{* *}$ & $-0,226^{* *}$ & 0,55 \\
\hline
\end{tabular}

Duygusal bağlılık değişkeninin psikolojik sözleşme ihlalinin görev performansina etkisinde tam aracı rolü (etki oranı $1,00)$, işgören sesliliğine etkisinde ise kısmi aracı rolü (etki oranı 0,55 ) üstlendiği ortaya çıkmıştır. Dolayısıyla H2a ve $\mathrm{H} 2 \mathrm{~b}$ hipotezleri de desteklenmiştir.

\section{Sonuç ve Öneriler}

Çalışanların ortaya koydukları iş performansı örgütler açısından hedeflenen amaçlara ulaşılabilmesinde önemli belirleyiciler arasında yer almaktadır. Yüksek bir iş performansının ortaya çıkarılabilmesinde çalışanların algılamaları ve tutumları etkili olabilmektedir. Bu çalışma kapsamında psikolojik sözleşme ihlali ve duygusal bağlılık, iş performansı (görev performansı ve işgören sesliliği) üzerinde etkili olan değişkenler olarak ele alınmıştır. Psikolojik sözleşme ihlali iş performansı üzerinde zayıflatıcı bir etkileyen olup, duygusal bağlılık önemli bir aracılık rolünü üstlenmiştir. 
Araştırmanın değişkenlerine ilişkin çalışanların algılamaları incelendiğinde, en çoktan en aza doğru görev performansı, işgören sesliliği, duygusal bağlılık ve psikolojik sözleşme ihlali olarak sıralanmıştır. Çalışanların psikolojik sözleşme ihlal algılamaları katılmıyorum seviyesine yakındır. İş performansları ise katılıyorum seviyesindedir.

Psikolojik sözleşme ihlalinin görev performansı ve işgören sesliliğini negatif olarak etkilediği çalışmanın ulaşılan temel bulgularındandır. İhlal algılaması zorunlu olarak gösterilmesi gereken ve gönüllü olarak gösterilen davranışları azaltmaktadır. Psikolojik sözleşme ihlalinin görev performansı üzerinde negatif etkisine ilişkin ulaşılan bu sonuç, yazında yapılan çalışmaların sonuçlarını (Hussain vd., 2016; Zhao vd., 2007; Restubog vd., 2007; Restubog vd., 2006; Johnson ve O'Leary-Kelly, 2003) ve sosyal değişim teorisini (Blau, 1964) desteklemektedir. Ayrica ihlalin rol ötesi performanslardan sayılan işgören sesliliği üzerine negatif etkisine ilişkin ulaşılan sonuç da yazındaki benzer çalışmaların (diğer rol ötesi performanslar) sonuçlarıyla uyuşmaktadır (Bal vd., 2011; Bal vd., 2010; Restubog vd., 2007). Bununla birlikte bu çalışmada psikolojik sözleşme ihlali rol ötesi performanslardan biri olarak alınan işgören sesliliği üzerinde görev performansına göre daha çok etkiye sahip olduğu tespit edilmiştir. Başka bir ifade ile psikolojik sözleşme ihlali işgören sesliliğini daha yüksek bir beta katsayısı ile negatif olarak etkilemiştir. Çalışanlar, rol ötesi performanslar konusunda görev performansindan daha fazla takdir yetkisine sahip olmaları nedeniyle (Bal vd., 2011) ihlal durumlarında bu tür davranışları daha fazla azaltabilirler.

Duygusal bağlılı̆̆ın psikolojik sözleşme ihlalinin görev performansını etkilemesinde tam aracılık, işgören sesliliğini etkilemesinde ise ortaya çıkan kısmi aracılık rolü çalışmanın ulaşılan diğer temel bulgularıdır. Psikolojik sözleşme ihlalinin görev performansına negatif etkisi duygusal bağlılığın varlığında ortaya çıkmaktadır. Buna karşılık duygusal bağlılık psikolojik sözleşme ihlalinin işgören sesliliği üzerindeki negatif olan etkisini azaltmıştır. Başka bir ifade ile psikolojik sözleşme ihlalinin işgören sesliliği üzerine etkisi azalarak da olsa devam etmiştir. Dolayısıyla psikolojik sözleşme ihlali gönüllü davranışlardan biri olan işgören sesliliği üzerine negatif etkisini duygusal bağlılığa rağmen sürdürmüştür.

Ulaşılan temel bulgular kapsamında psikolojik sözleşme ihlali çalışanların duygusal bağlılık ve iş performansları üzerinde önemli bir örgütsel hadise olarak ortaya çıkmıştır. Dolayısıyla yöneticilerin üzerinde hassasiyetle çalışmaları gereken bir konudur. Çünkü bu çalışmanın da gösterdiği gibi ihlal halinin duygusal bağlılık, görev performansı ve işgören sesliliği üzerinde olumsuz etkisi söz konusudur. İncelenen sonuç değişkenlerin hem çalışanlar hem de örgütler lehine ortaya koyduğu avantajlar değerlendirildiğinde psikolojik sözleşme ihlalinin ne kadar dezavantajlı bir durum olduğu görülecektir. $\mathrm{Bu}$ bakımdan yöneticilerin çalışanlarla kurdukları beklentilerin karşılanması, verilen vaatlerin tutulmasında hassasiyet göstermeleri gerekmektedir. Çünkü çalışanlar yerine getirilmeyen vaat, karşılanmayan beklenti ya da katkılarının karşılığını alamadıkları algılamasına sahip olduklarında sözleşmeye dair zihinlerinde ihlal algısı oluşabilecektir. Dolayısıyla yöneticilerin verilen sözleri yerine getirmeleri, sözlerinden dönmemeleri ve çalışanların örgüte sundukları katkıların karşılığını kendilerine teslim etmeleri konularındaki başarıları sözleşme ihlal algılamasının ortaya çıkmasına engel olabilecektir. Aksi takdirde bilişsel bir durum olan ihlal algılaması çeşitli olumsuz hisler ortaya çıkarabilecek ve bunun sonucunda da psikolojik sözleşme zarar görebilecek ya da bozulabilecektir. $\mathrm{Bu}$ durum yapılan çalışmanın da ortaya çıkardığı gibi çalışanların özellikle biçimsel iş tanımlarında yer almayan, gönüllü olarak yerine getirdikleri davranışları negatif olarak daha çok etkileyebilecektir.

Yapılan çalışmanın diğer çalışmaların da sahip olduğu gibi çeşitli kısıtları söz konusudur. Örneklem verilerinin sadece bir bölge ve sektörden seçilmesi ve bir zaman diliminde toplanması sınırlılıklar olarak ortaya çıkmıştır. Dolayısıyla ulaşılan sonuçların bu kısıtlılıklar kapsamında değerlendirilmesi gerekmektedir. Bu konularda çalışma yapacaklara ise, çalışmanın sonuç değişkenlerine örgütsel vatandaşlık davranışı, bilgi paylaşımı, işgören sessizliği, sosyal kaytarma davranışlarını katarak etik iklim, prosedürel adalet gibi düzenleyicilerle incelemeleri önerilebilir.

\section{Kaynakça}

Allen, N.J., \& Meyer, J.P. (1990). The Measurement and Antecedents of Affective, Continuance and Normative Commitment to the Organization. Journal of Occupational Psychology, 63(1), 1-18.

Argyris, C. (1960). Understanding Organizational Behaviour. First Edition, London: Tavistock Publications.

Arslan, A., \& Yener, S. (2016). İşgören Sesliliği Ölçeğinin Türkçe'ye Uyarlanması Çalışması. Yönetim ve Ekonomi Araştırmaları Dergisi, 14(1), 173-191.

Aslan, Ş., \& Uyar, S. (2018). Psikolojik Sözleşme İhlali ile Hissettirdiklerinin Örgütsel Özdeşleşme, İş Tatmini ve İşten Ayrılma Niyeti Üzerine Etkileri. Dokuz Eylül Üniversitesi, İktisadi ve İdari Bilimler Fakültesi Dergisi, 33(1), 1-38.

Bağcı, Z. (2014). Çalışanların İş Doyumunun Görev ve Bağlamsal Performansları Üzerindeki Etkisi. Yönetim ve Ekonomi Araştırmaları Dergisi, 24, 58-72.

Bal, P.M., Chiaburu, D.S., \& Diaz, I. (2011). Does Psychological Contract Breach Decrease Proactive Behaviors? The Moderating Effect of Emotion Regulation. Group \& Organization Management, 36(6), 722-758.

Bal, P.M., Chiaburu, D.S., \& Jansen, P.G.W. (2010). Psychological Contract Breach and Work Performance. Journal of Managerial Psychology, 25(3), 252-273.

Bal, P.M., Lange, A.H., Jansen, P.G., \& Velde, M.E. (2008). Psychological Contract Breach and Job Attitudes: A Meta Analysis of Age as a Moderator. Journal of Vocational Behavior, 72, 143-158.

Baron, R.M. \& Kenny, D.A. (1986). The ModeratorMediator Variable Distinction in Social Psychological Research: Conceptual, Strategic, and Statistical Considerations. Journal of Personality and Social Psychology, 51(6),1173-1182. 
Blau, P.M. (1964). Exchange and Power in Social Life. New York: Wiley.

Beardwell, J., \& Claydon, T. (2007). Human Resource Management: A Contemporary Approach. 5th Ed., Harlow, UK: Prentice Hall.

Befort, N., \& Hattrup, H. (2003). Valueing Task and Contextual Performance: Experience, Job Roles and Rating of The İmportance of Job Behaviours. Applied H.R.M.Research, 8(1), 17-32.

Borman, W.C., \& Motowidlo, S.J. (1997). Task Performance and Contextual Performance: The Meaning for Personnel Selection Research. Human Performance, 10, 99-109.

Chin, W.W., Marcolin, B.L., \& Newsted, P.R. (2003). A Partial Least Squares Latent Variable Modeling Approach For Measuring İnteraction Effects: Results From A Monte Carlo Simulation Study and An Electronic-Mail Emotion/Adoption Study. Information Systems Research, 14(2), 89-217.

Chin, W.W. (2001). PLS-graph User's Guide Version 3.0. Houston, Texas: C.T. Bauer College of Business, University of Houston.

Cropanzano, R., Rupp, D.E., \& Byrne, Z.S. (2003). The Relationship of Emotional Exhaustion to Work Attitudes, Job Performance, and Organizational Citizenship Behaviors. Journal of Applied Psychology, 88(1), 160619.

Çetinkaya, F.F. (2018). Psikolojik Sözleşme İhlalleri ve Örgütsel Sinizm İlişkisi. İşletme Araştırmaları Dergisi, 10(1), 652-674.

Doğan, S., \& Demiral, Ö. (2009). Örgütsel Bağlılığın Sağlanmasında Personel Güçlendirme ve Psikolojik Sözleşmenin Etkisine İlişkin Bir Araştırma. Erciyes Üniversitesi İktisadi ve İdari Bilimler Fakültesi Dergisi, $32,47-80$.

Doğan, D. (2019). Smartpls Ile Veri Analizi (2. Baskl). Ankara: Zet Yayınları.

Field, A.P. (2000). Discovering Statistics Using SPSS for Windows. London: Sage Publications.

Fornell, C., \& Larcker, D.F. (1981). Evaluating Structural Equation Models with Unobservable Variables and Measurement Error. Journal of Marketing Research, 18, 39-50.

Hair, J.F.Jr., Hult, T.M., Ringle, C.M., \& Sarstedt, M. (2013). A primer on partial least squares structural equation modeling (pls-sem). Thousand Oaks. CA: Sage.

Hair, J.F.Jr., Black, W.C., Babin, B.J., Anderson, R.E., \& Tatham, R.L. (2006). Multivariate Data Analysis. 6th Ed., New Jersey: Pearson Prentice Hall.

Harrison, D.A., Newman, D.A., \& Roth, P.L. (2006). How Important are Job Attitudes? Meta-Analytical Comparisons of Integrative Behavioral Outcomes and Time Sequences. Academy of Management Journal, 49, 305-325.

Hussain, S., Gul, H., Usman, M., \& Ul Islam, Z. (2016). Breach of Psychological Contract, Task Performance,
Workplace Deviance: Evidence from Academia in Khyber Pukhtunkhwa, Pakistan. International Business and Management, 13(2), 12-20.

Johnson, J.L., \& O'Leary-Kelly, A.M. (2003). The Effects of Psychological Contract Breach and Organizational Cynicism: Not All Socail Exchange Violations are Created Equal. Journal of Organizational Behavior, 24(5), 627-647.

Knights, J.A., \& Kennedy, B.J. (2005). Psychological Contract Violation: Impacts on Job Satisfaction and Organizational Commitment Among Australian Senior Public Servants. Applied H.R.M. Research, 10(2), 57-72.

Levinson, H., Price, C.R., Munden, K.J., Mandl, H.J., \& Solley, C.M. (1962). Men, Management, and Mental Health. Cambridge, MA, US: Harvard University Press.

MacKinnon, D.P., Lockwood C.M., \& Williams, J. (2004). Confidence Limits for The Indirect Effect: Distribution of The Product and Resampling Methods. Multivariate Behavioral Research, 39(1), 99-128.

McShane, S.L., \& Glinow, M.A.V. (2014). Organizational Behavior. Second Edition, New York: McGraw-hill Irwin.

Meyer, J.P., \& Allen, N.J. (1991). A Three-Component Conceptualization of Organizational Commitment. Human Resources Management Review, 1, 61-89.

Mimaroğlu, H. (2008). Psikolojik Sözleşmenin Personelin Tutum ve Davranışlarına Etkileri: Tıbbi Satış Temsilcileri Üzerinde Bir Araştırma. Doktora Tezi. Adana: Çukurova Üniversitesi.

Morrison, E.W., \& Robinson, S.L. (1997). When Employees Feel Betrayed: A Model of How Psychological Contract Violation Develops. Academy of Management Review, 22(1), 226-256.

Naeem, A.T., Ihsan, F., \& Mahmood, Z. (2014). The Study of Organizational Justice, Violation of Psychological Contract and its Effect on Job Satisfaction in Paints Industry of Pakistan. International Journal of Academic Research in Business and Social Sciences, 4(12), 244458.

Örücü, E., \& Korkmaz, E. (2018). Psikolojik Sözleşme İhlali ve Duygusal Emek İlişkisi: Sağlık Sektöründe Bir Araştırma. Balıkesir Üniversitesi Sosyal Bilimler Enstitüsü Dergisi, 21(40), 337-349.

Podsakoff, P.M., MacKenzie, S.B., Paine, J.B., \& Bachrach, D.G. (2000). Organizational Citizenship Behaviors: A Critical Review of The Theoretical and Empirical Literature and Suggestions For Future Research. Journal of Management, 26, 513-563.

Restubog, S.L.D., Bordia, P., \& Tang, R.L. (2007). Behavioural Outcomes of Psychological Contract Breach in a Non-Western Culture: The Moderating Role of Equity Sensitivity. British Journal of Management, 18(4), 376-386.

Restubog, S.L.D., Bordia, P., \& Tang, R.L. (2006). Effects of Psychological Contract Breach on Performance of IT Employees: The Mediating Role of Affective 
Commitment. Journal of Occupational and Organizational Psychology, 79, 299-306.

Rousseau, D.M. (1995). Psychological Contracts in Organizations: Understanding Written and Unwritten Agreements. London: Sage Publications.

Robinson, S.L. (1996). Trust and Breach of the Psychological Contract. Administrative Science Quarterly, 41(4), 574-599.

Robinson, S.L., \& Morrison, E.W. (2000). The Development of Psychological Contract Breach and Violation: A Longitudinal Study. Journal of Organizational Behavior, 21(5), 525-546.

Robinson, S.L., \& Morrison, E.W. (1995). Psychological Contracts and OCB: The Effect of Unfulfilled Obligations on Civic Virtue Behavior. Journal of Organizational Behavior, 16(3),189-298.

Robinson, S.L., \& Rousseau, D.M. (1994). Violating the Psychological Contract: Not the Exception but the Norm. Journal of Organizational Behavior, 15, 245-259.

Shrout, P.E., \& Bolger, N. (2002). Mediation in Experimental and Nonexperimental Studies: New Procedures and Recommendations. Psychological Methods, 7(4), 422-445.

Smithson, J., \& Lewis, S. (2004). The Psychological Contract and Work-Family. Organization Management Journal, 1(1), 70-80.

Tabachnick, B.G., \& Fidell, L.S. (2013). Using Multivariate Statistics (6th ed.). Boston, MA: Pearson Education.

Türkiye Bankalar Birliği Veri Sistemi, (2018). https://www.tbb.org.tr/tr/bankacilik/banka-ve-sektorbilgileri/veri-sorgulama-sistemi/illere-ve-bolgeleregore-bilgiler/73 Erişim Tarihi:11.07.2019.

Turnley, W.H., \& Feldman, D.C. (1998). Psychological Contract Violations During Corporate Restructuring. Human Resource Management, 37(1), 71-83.
Tükeltürk, Ş.A., Perçin, N.Ş., \& Güzel, B. (2012). Psikolojik Kontrat İhlal Algısı ile Örgütsel Bağlılık İlişkisi: Otel İşletmeleri Üzerine Bir Araştırma. Yönetim Bilimleri Dergisi, 10(20), 93-110.

Wasti, S.A. (2000). Meyer ve Allen'in Üç Boyutlu Örgütsel Bağlllık Ölçeğinin Geçerlik ve Güvenirlik Analizi. 8. Ulusal Yönetim ve Organizasyon Kongresi, 401-410.

Williams, L.J., \& Anderson, S.E. (1991). Job Satisfaction and Organizational Commitment as Predictors of Organizational Citizenship and In-Role Behaviors. Journal of Management, 17(3), 601-617.

Van Dyne, L., Cummings, L.L., \& McLean P.J. (1995). Extra-Role Behaviours: In Pursuit of Construct and Definitional Clarity (a Bridge over Muddied Waters). In Cummings, L. L., \& Staw, B. M. (Eds.) Research in Organizational Behavior, 17, 215-285.

Van Dyne, L., \& LePine, J.A. (1998). Helping and Voice Extra-role Behavior. Evidence of Construct and Predictive Validity. Academy of Management Journal, 41, 108-119.

Varol, F. (2017). Çalışanların Örgütsel Bağlılık ve İş Tatminlerinin İşten Ayrılma Niyetlerine Olan Etkisi: İlaç Sektörü Örneği. Selçuk Üniversitesi Sosyal Bilimler Enstitüsü, 38, 200-208.

Weiss, H.M., \& Cropanzano, R. (1996). Affective Events Theory: A Theoretical Discussion of the Structure, Cases and Consequences of Affective Experiences at Work. Research in Organizational Behavior, 18, 1-74.

Yorulmaz, M. (2018). Tersane Çalışanlarının Duygusal Bağlılık Düzeylerinin İş Performansları Üzerindeki Etkisi: Yalova Örneği. Uluslararası Sosyal Araştırmalar Dergisi, 11(56), 869-876.

Zhao, H., Wayne, J. Sandy, G., Brian, C., \& Bravo, J. (2007). The Impact of Psychological Contract Breach on Workrelated Outcomes: A Meta-Analysis. Personnel Psychology, 60(3), 647-680. 